UNITED STATES DEPARTMENT OF THE INTERIOR GEOLOGICAL SURVEY

MINERALOGY, DIAGENESIS, AND PROVENANCE OF UPPER CRETACEOUS SANDSTONES FROM THE RALSTON PRODUCTION COMPANY FEDERAL NO. 31 WELL, PICEANCE CREER BASIN, NORTHWESTERN COLORADO

\title{
By
}

Paula L. Hansley

Open-File Report 81-1295

1981

This report is preliminary and has not been reviewed for conformity with U.S. Geological Survey editorial standards 


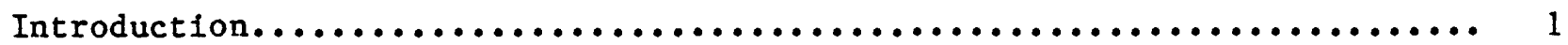

Detrital Mineralogy.......................................... 3

Diagenesis................................................

Paragenesis................................................... 14

Provenance.................................................. 17

Summary $. \ldots \ldots \ldots \ldots \ldots \ldots \ldots \ldots \ldots \ldots \ldots \ldots \ldots \ldots \ldots \ldots \ldots \ldots \ldots, 18$

References............................................ 20

Tables

Table 1. Results of 300-point counts, Ralston core, southeastern

Piceance Creek basin, Colorado........................ 4

Table 2. X-ray diffraction data from bulk rock samples.

Numbers represent major peak heights.................... 13

Figures

Figure 1.--Index map of Piceance Creek basin, northwestern Colorado, showing locations of some coreholes and measured sections......

Figure 2.--Ternary diagram showing composition of sandstones from

the Ralston core..................................

Figure $3 a$ and b.-Photomicrographs of lgneous rock fragments from sample 78-11 $\left(3636^{\prime}\right)$, Mesaverde Formation, Ralston core: (a) fragment with

pilotaxitic texture and (b) fragment with feldspar phenocryst.. 8 Figure $4 \mathrm{a}$ and b.--Photomicrographs of sample 78-12 (3630') from the Mesaverde Formation, Ralston core: (a) authigenic, twinned albite lath, and (b) albite overgrowth on detrital plagioclase feldspar........ 12 


\section{MINERALOGY, DIAGENESIS, AND PROVENANCE OF UPPER CRETACEOUS SANDSTONES FROM THE RALSTON PRODUCTION COMPANY FEDERAL NO. 31 WELL, PICEANCE CREER BASIN, NORTHWESTERN COLORADO ${ }^{1}$}

By

Paula L. Hansley

\section{INTRODUCTION}

As part of a study of "tight" sandstones (permeability $<0.1$ millidarcy) in Western Interior basins, Upper Cretaceous nonmarine sandstones of the Mesaverde Formation were examined in order to evaluate their mineralogy and diagenetic history. Core samples were taken from the Ralston Production Company Federal No. 31 well located in sec. 31 , T. 10 S., $R 90$ W. in the southeastern part of the Piceance Creek basin (fig. 1). The uppermost unit sampled is approximately $1200^{\prime}$ below the regional unconformity separating Cretaceous and Tertiary rocks; pollen data from the uppermost Mesaverde Formation to the southeast fix a minimum age for those sandstones as late Campanian (Johnson and May, 1980).

Thirteen samples from the core were studied petrographically and modal compositions determined; ten samples were selected for bulk X-ray diffraction; and two samples were analyzed by the electron microprobe for determination of the composition of feldspar overgrowths. The petrographic samples were stained with sodium cobaltinitrate for K-feldspar identification and with Alizarin Red-S for calcite identification. One slide from each sample was impregnated with blue epoxy for evaluation of porosity.

${ }^{1}$ Supported in part by the U.S. Department of Energy. 


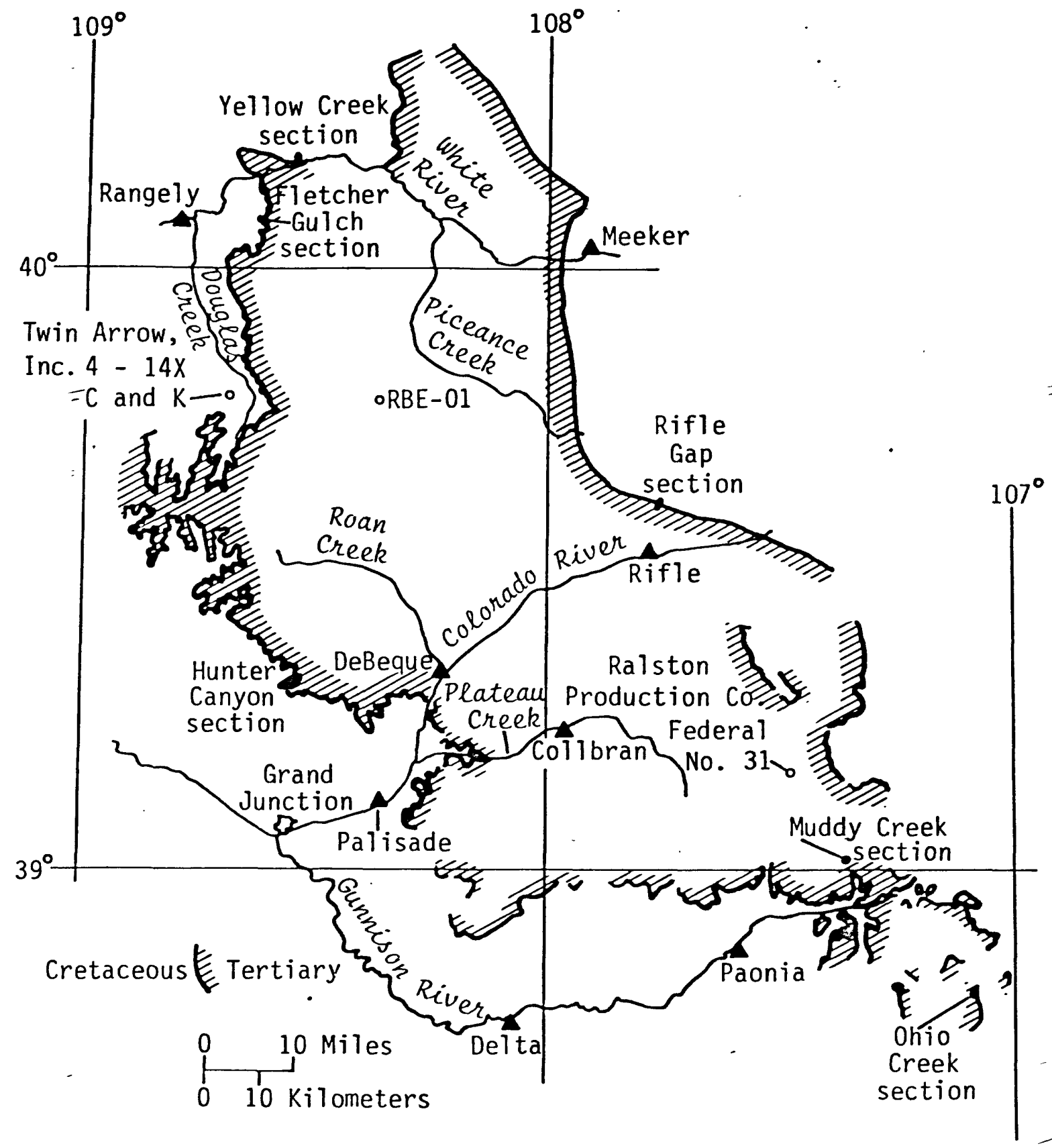

Figure 1.--Index map of Piceance Creek basin, northwestern Colorado, showing locations of some coreholes and measured sections. 


\section{DETRITAL MINERALOGY}

Three hundred-point counts of each thin section were tabulated (table 1); most of the sandstones were classified (Folk, 1968) as 1ithic arkoses (fig. 2). Detrital grains are generally subangular to subrounded, fine to coarse grained, and moderately sorted. They include quartz, K-feldspar, plagioclase, chert, a variety of rock fragments, and various accessory minerals.

Quartz grains are monocrystalline and polycrystalline, clear and unstrained, although a few showing undulatory extinction occur in each sample. Occasionally, rounded detrital grains with overgrowths, possibly inherited from an earlier sedimentary cycle, were noted. Large, fresh and angular $\mathrm{K}$-feldspar and plagioclase grains occur more abundantly in this core than in sandstones of the Mesaverde Formation (or Group) examined from other parts of the basin (Hansley and Johnson, 1980). X-ray diffraction indicated that Na-plagioclase is more abundant than $\mathrm{K}$-feldspar (table 2); however, much of the Na-plagioclase is present as authigenic albite, not as detrital grains. Microcline appears to be at least as common as orthoclase. Plagioclase grains are primarily angular cleavage fragments which often display simple albite twinning. They are usually more altered than K-feldspar grains; the alteration is commonly seriticization and (or) albitization and, occasionally, replacement by calcite or kaolinite. The few grains which are extensively seriticized are usually rounded suggesting that at least some of the alteration was inherited from an earlier sedimentary cycle.

One of the most interesting aspects of these sandstones is that the mineralogy of the rock fragments is different from that of other sandstones from the upper nonmarine part of the Mesaverde in the basin because it includes an abundance of igneous as well as less common metamorphic and sedimentary types. Identification of rock fragments is very difficult in 


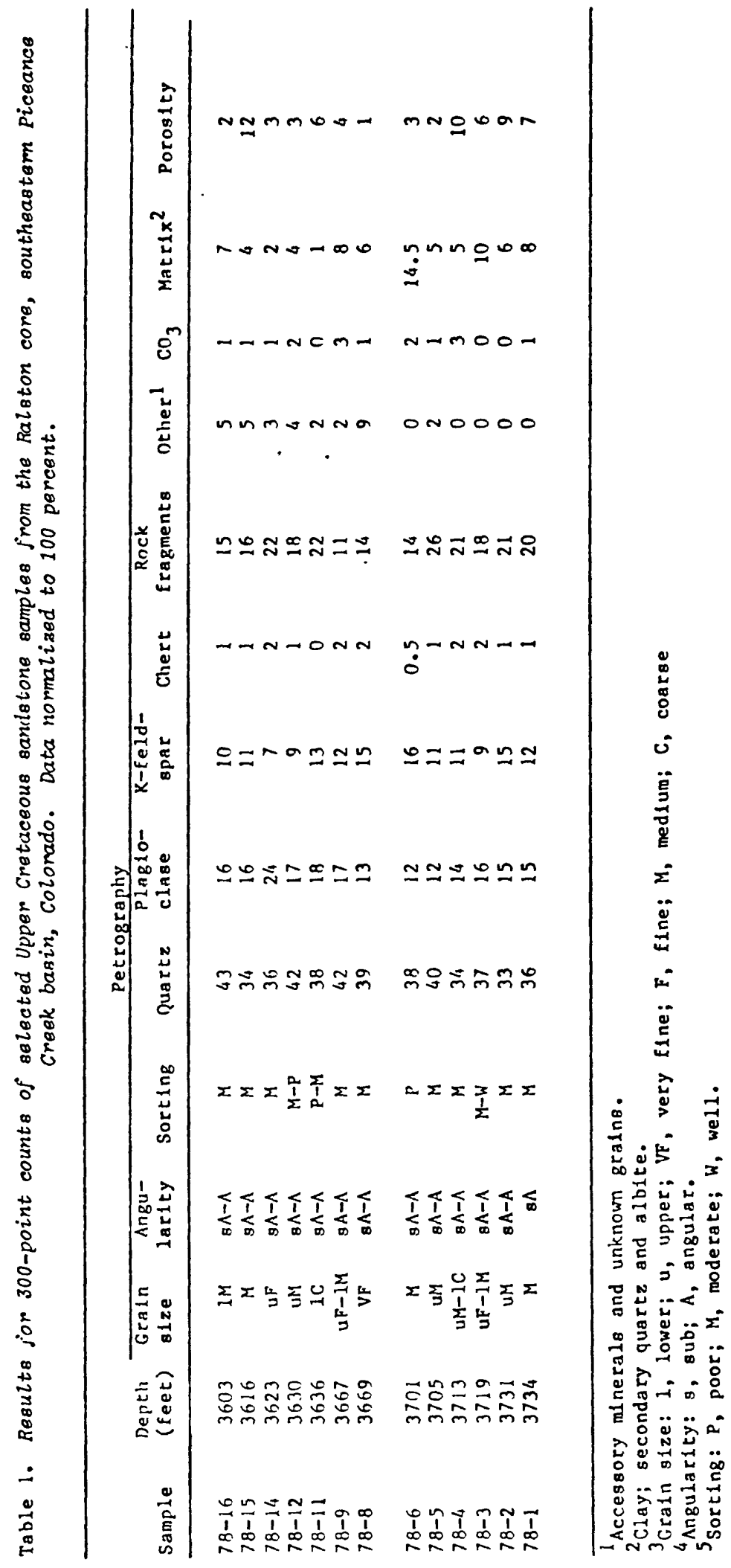




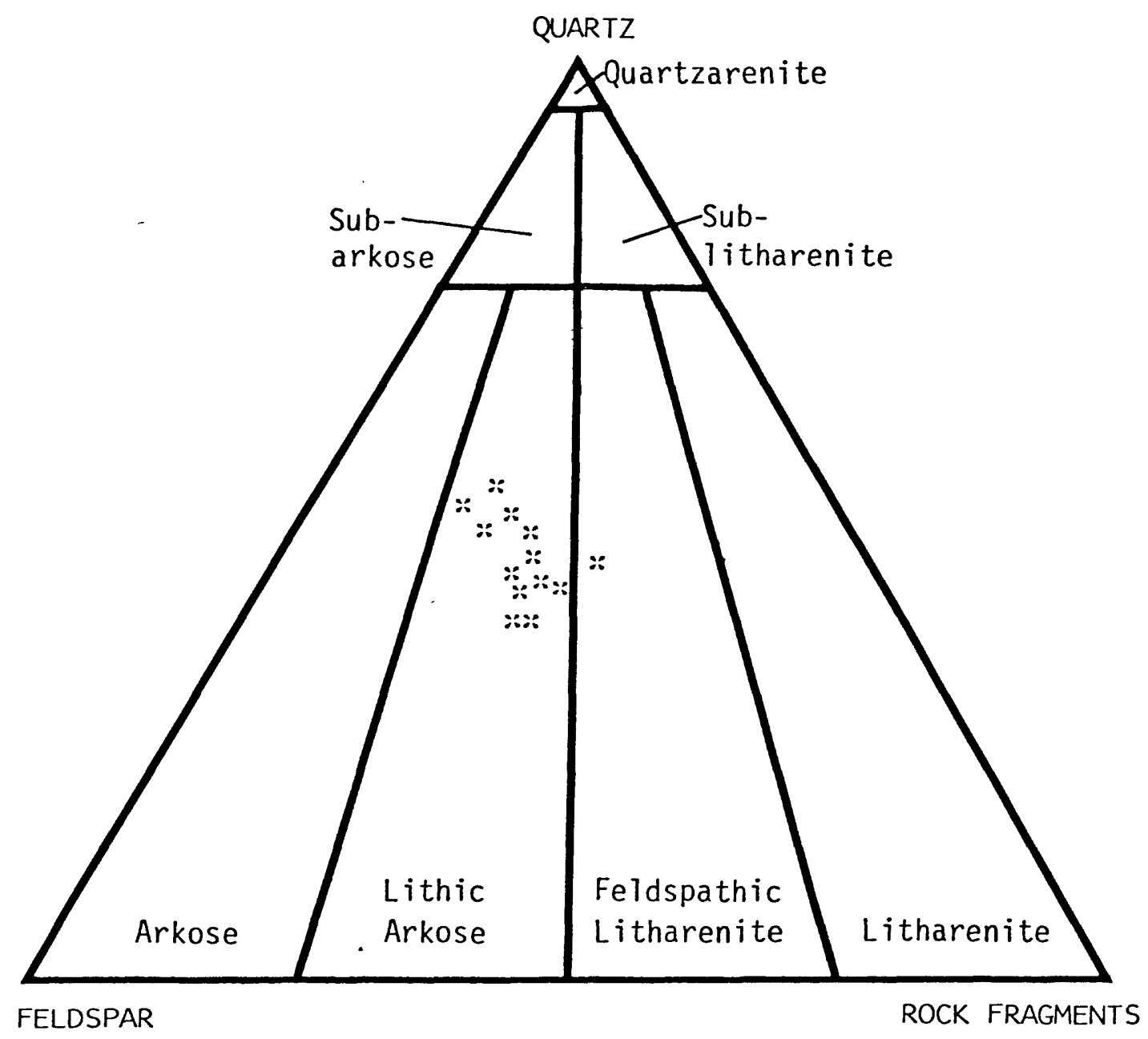

Figure 2.--Ternary diagram showing composition of sandstones from the Ralston core (Folk, 1968). 
fine-grained sedimentary rocks. According to Boggs (1968), fine-grained igneous rock fragments can be recognized even in fine-grained sandstones because of their distinctive textures. This is not as true of the coarser grained igneous rock types. It is primarily on the basis of textures that the tentative identifications of the fine-grained igneous rock fragments in samples from the Ralston core have been made.

Microgranite, microgranodiorite, andesite(?), and possibly other igneous varieties with aplitic, felsitic, and pilotaxitic textures comprise 50 percent or more of the rock fragment types. (Moorhouse, 1959). More than 50 percent of the igneous rock fragments are aplitic consisting of an even-grained groundmass of feldspar laths. Some fragments are porphyritic with elongate feldspar laths arranged in a pilotaxitic texture (fig. 3a) with an occasional plagioclase or mafic phenocryst such as pyroxene. Rarely, the alteration of iron-bearing minerals has created dark brown opaque rock fragments with plagioclase laths apparently floating in the dark groundmass. The more felsic lithic fragments often display secondary, euhedral albite laths up to $.05 \mathrm{~mm}$ long projecting from their outside surfaces into pores. Less common felsitic fragments occasionally have feldspar phenocrysts in a gray, low birefringent, groundmass (fig. $3 b$ ). 
A few metamorphic grains, mainly metaquartzite and chlorite schist, occur In each thin section. Metaquartzite grains are small and rounded, suggesting that they have been recycled from older sediments and (or) that they have travelled a greater distance from their source area. Chloritic fragments comprise 1 to 2 percent of the rock fragment fraction. Argillaceous, finegrained sedimentary rock fragments and chert are the least abundant lithic fragments in these sandstsone. Small fragments of chert comprise less than 5 percent of the detrital fraction.

In thin section, accessory minerals noted include muscovite, biotite, chlorite, garnet, hornblende, pyroxene, sphene, tourmaline, iron-titanium oxides, zircon, and apatite. Micas are the most common accessories and biotite, in some cases, appears to be altering to chlorite. Hornblende and pyroxenes are present in each sample; often, pyroxenes occur as composite grains showing patchy extinction. Relict magnetite or ilmenite occur within masses of leucoxene which has formed as a result of alteration of the detrital Fe-Ti oxide grains.

Tar-like organic material is present locally. In the silty and very fine grained samples it occurs in laminae associated with accessory heavy minerals. 


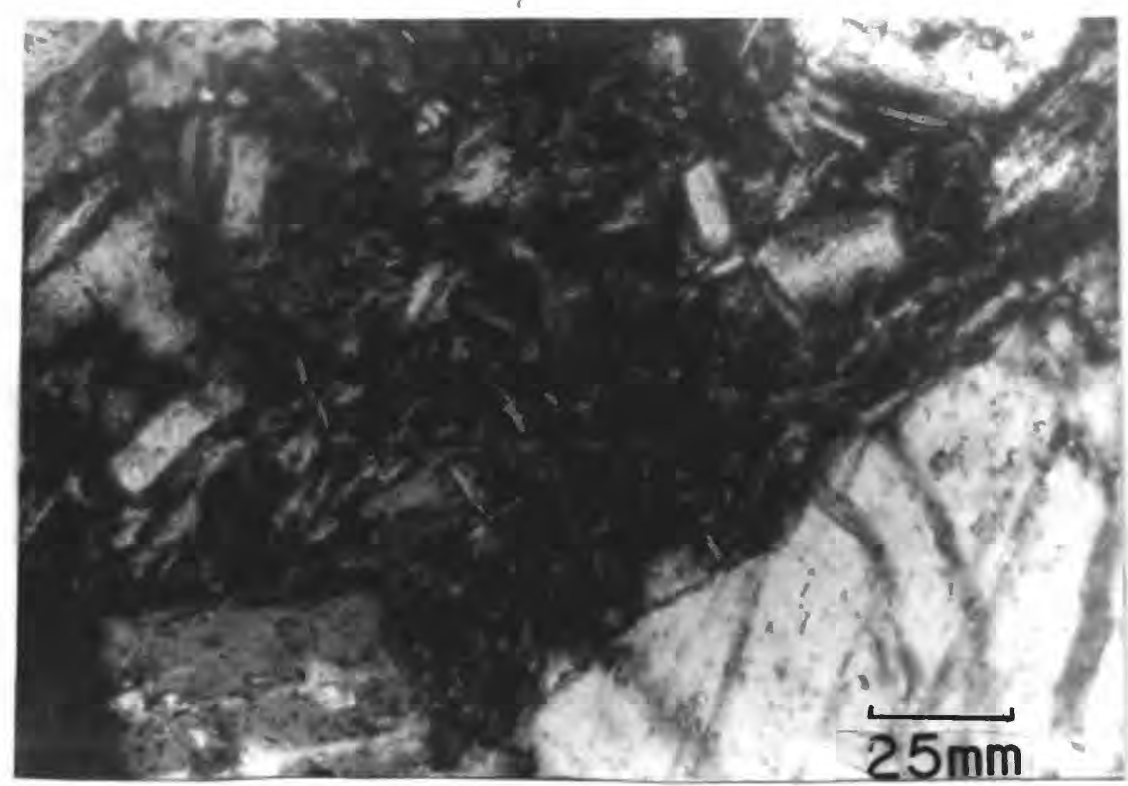

(a)

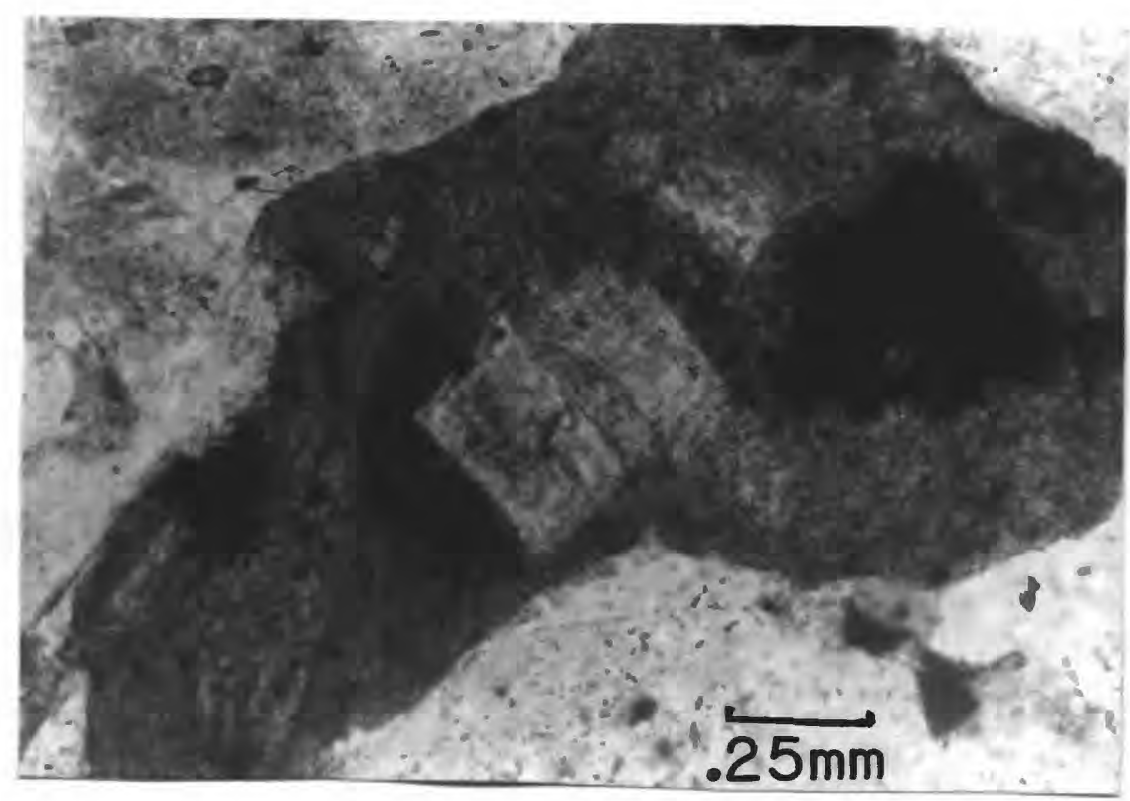

(b)

Figure $3 a$ and b.--Photomicrographs (plain light) of igneous rock fragments from sample 78-11 (3636'): (a) fragment with pilotaxitic texture and (b) fragment with feldspar phenocrysts. 


\section{DIAGENESIS}

The diagenetic history of these sandstones is represented by an array of secondary minerals of which chlorite, albite, silica, calcite, sericite and kaolinite are the major types. Minor authigenic constituents include pyrite, titanium dioxide minerals, and hematite.

Chlorite occurs as plates oriented perpendicularly to detrital grain surfaces, as rims bordering pores, and as fracture fillings in grains. It is present rarely on quartz overgrowths, but is more frequently found between both quartz and feldspar overgrowths and their respective detrital grains. Chlorite is often associated with an unoriented mixed-layer(?) clay which also coats grain surfaces and may, in part, be detrital.

Authigenic feldspar, which was tentatively identified as albite by electron microprobe analysis, is a very important diagenetic mineral. It is ubiquitous, often totally cementing large areas of framework. The morphology of the albite varies: it occurs as secondary rims in optical continuity with the detrital grains of plagioclase and $\mathrm{K}$-feldspar and as delicate euhedral laths projecting into pores from detrital feldspathic rock fragments and feldspars (fig. 4b). Authigenic albite rarely contains more than 3 molecular percent $\mathrm{K}$-feldspar and usually less than .3 molecular percent Ca-plagloclase (Deer and others, 1978). The microprobe analysis indicated that the albite is, in fact, almost a pure sodium end-member. Many of the albite crystals, when viewed under high power (e.g. 500X), display simple growth twins (fig. 4a). Dissolution of framework silicate grains, and possibly the vitric matrix of volcanic rock fragments, may have created a chemical environment favorable for the formation of authigenic albite. 
Silica overgrowths, which occur locally throughout these sandstone, often display sharp euhedral outlines. Authigenic silica drastically reduces the porosity in areas where overgrowths from adjacent detrital quartz grains have coalesced to form a solid mass of silica. Euhedral albite laths can occasionally be seen completely engulfed by authigenic silica.

Calcite replaces detrital feldspar and lithic grains to a limited degree and also occurs as a pore-filling cement. Some pores which are rimmed with chlorite and quartz overgrowths are completely filled with sparry calcite. Delicate authigenic albite crystals occur within calcite cement which has apparently filled in the void around them.

$\mathrm{X}$-ray diffractograms of the bulk rock indicate that kaolinite, illite, (plus sericite), and minor amounts of mixed-layer clay are present (table 2). Kaolinite occurs as a pore filling, as replacement of earlier cements, and as an alteration product of feldspars and lithic fragments. Illite was not identified in thin section; however, the fact that many plagloclase grains are sericitized indicates that the "illite" peak on the X-ray diffractograms may be due, in large part, to the presence of finely crystalline sericite. Mixed layer clay is present in trace amounts with the exception of samples 78$6(?)$ and 78-9 where it is more common. It is interpreted to be present as either a detrital, or possibly as a very early, diagenetic grain coating. 
Figure $4 a$ and b.--Photomicrographs (crossed polars) of sample 78-12 (3630') from the Mesaverde Formation, Piceance Creek basin: (a) authigenic twinned albite laths and (b) albite overgrowth on detrital plagioclase feldspar. Q, detrital quartz; F, detrital plagioclase feldspar; $R$, rock fragment; $Q 0$, quartz overgrowth; a, authigenic albite; a (with arrow), authigenic, twinned albite lath; c, authigenic calcite; $v$, void. 


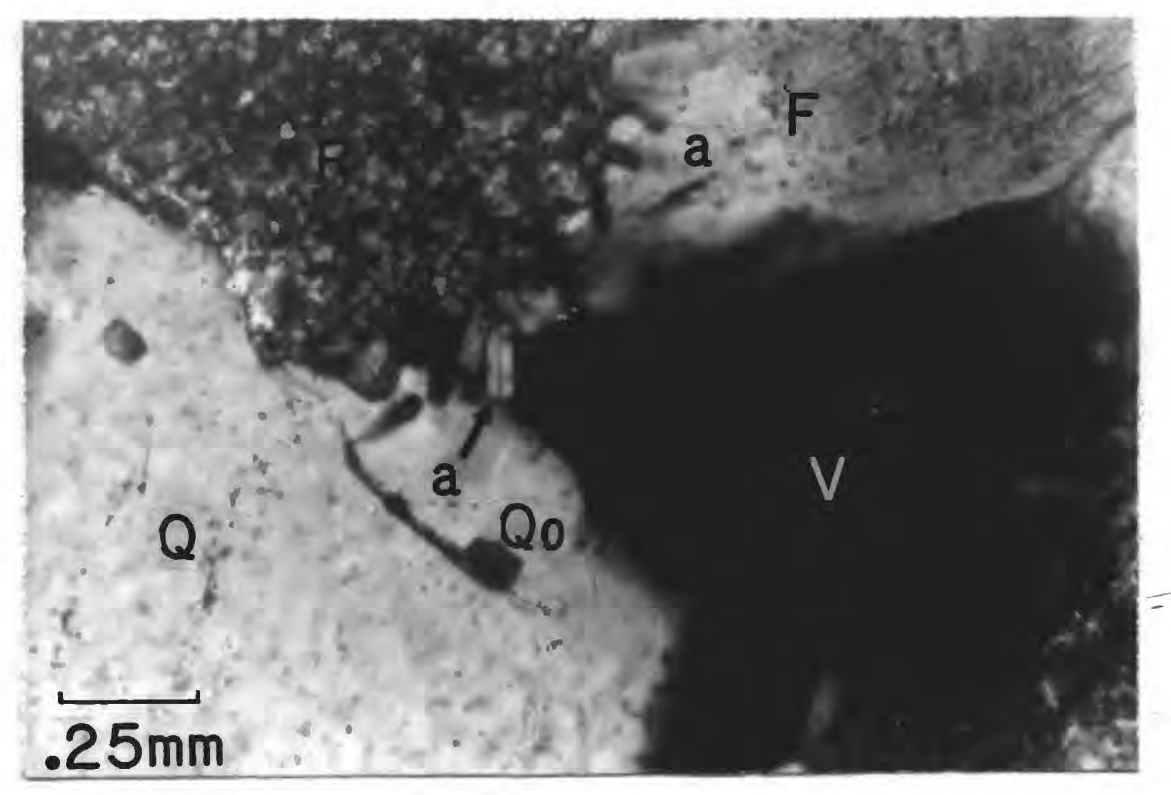

(a)

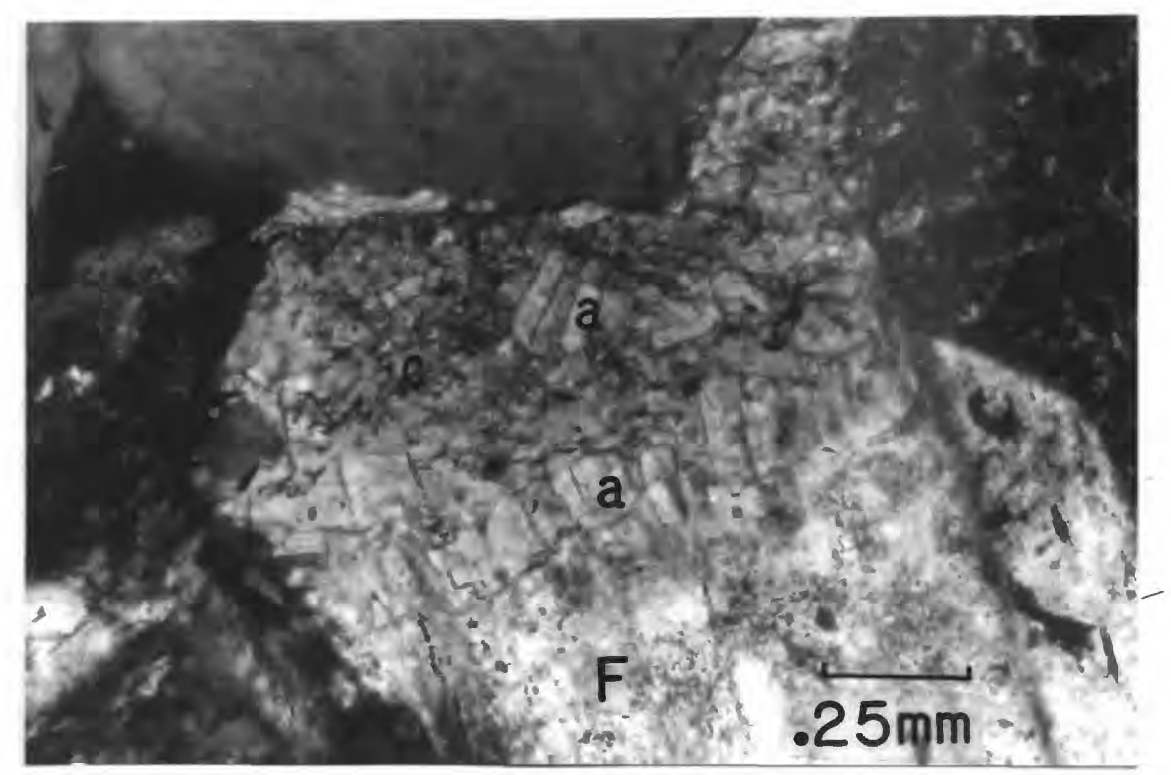

(b) 
Table 2.--X-ray dijjraction data jrom bulk rock samples.

Numbers represent major peak heights.

\begin{tabular}{ccccccc}
\hline Sample No. & Na-plagioclase & K-feldspar & Chlorite & $\begin{array}{c}\text { Illite } \\
\text { (Sericite) }\end{array}$ & $\begin{array}{c}\text { Mixed-layer } \\
\text { Clay }\end{array}$ & $\begin{array}{c}\text { Chloritet } \\
\text { Kaolinite }\end{array}$ \\
\hline $78-16$ & 49.4 & 29.6 & 2.0 & 2.0 & trace & 5.0 \\
$78-15$ & 58.0 & 18.3 & 2.7 & 3.1 & trace & 4.7 \\
$78-14$ & 70.0 & 27.2 & 3.5 & 3.2 & trace & 10.0 \\
$78-12$ & 92.0 & 24.2 & 2.9 & 2.0 & trace & 8.2 \\
$78-11$ & 89.8 & 59.1 & 2.9 & 2.3 & trace & 6.3 \\
$78-9$ & 59.0 & 22.3 & 2.0 & 2.7 & 4.0 & 4.3 \\
$78-5$ & 66.0 & 79.5 & 1.5 & 2.0 & 1.1 & 4.9 \\
$78-4$ & 88.8 & 41.1 & 2.2 & 1.6 & trace & 5.1 \\
$78-2$ & 62.5 & 36.5 & 2.8 & 3.0 & trace & 7.5 \\
$78-1$ & 89.3 & 37.5 & 3.5 & 3.3 & trace & 8.9 \\
& & & & & & \\
\hline
\end{tabular}


Minor diagenetic constituents are pyrite, titanium dioxides (e.g. leucoxene and anatase), and hematite. Authigenic pyrite occurs in nodules, in laminae associated with organic matter, and in local patches. It forms an opaque cement in large areas of two thin sections where it completely engulfs detrital grains. Within a pyrite mass in sample $78-9$, a few plagioclase grains are sericitized and some are partly replaced by calcite. Leucoxene, and rarely anatase, which formed as a result of the alteration of Fe-Ti oxide minerals, such as magnetite and 1lmenite, occurs as opaque white masses scattered throughout each thin section. Hematite is present infrequently and is also an alteration product of detrital Fe-Ti oxide grains.

Porosity varies from 1 to 12 percent with an average of 5.2 percent. Those samples with higher porosities have more moldic and intergranular porosity probably formed by more widespread solution of unstable grains and cements. Because of the extensive solution of unstable grains, it is difficult to determine how much porosity is primary.

\section{PARAGENESIS}

Soon after deposition, oxidation of detrital Fe-Ti oxides occurred with the formation of minor amounts of hematite and titanium oxide minerals. After burial and consolidation of these sediments, the first widespread diagenetic event is interpreted to have been solution of less stable detrital framework grains creating patchy intergranular and moldic porosity. It is unclear how much solution occurred at this stage because there is evidence for at least one stage of later solution of framework grains and cements. Early leaching was apparently facilitated by the high percentage of unstable lithic fragments in the rock. 
The formation of authigenic chlorite also occurred relatively early in the burlal history of these rocks. Chlorite is considered to be an early authigenic mineral because it occurs between detrital quartz and feldspar grains and their respective overgrowths. In addition, it rims pores which are filled with calcite. Some clay present on detrital grains may be detrital mixed-layer(?) clay on which the authigenic chlorite has formed. This clay is not oriented perpendicularly to grain surfaces and, unlike the chlorite, occurs at grain contacts.

Solution of framework grains, particularly fine-grained felsic fragments, probably increased the activity of pore fluids (e.g. especially $\mathrm{Na}^{+}$activity), so that an abundance of albite formed on detrital feldspars and rock fragments. In many cases (e.g. 78-12), these overgrowths engulf earlier chlorite rims and completely fill both primary(?) and secondary pores. Subsequently, and perhaps in part penecontemporaneously, quartz overgrowths formed on detrital quartz grains. Evidence that some secondary quartz post-dated the authigenic albite is the fact that the overgrowths often apparently surround euhedral albite grains. Relationships between secondary quartz and albite are not always clear because, occasionally, both appear to have grown at the same time into a void. In limited areas, quartz overgrowths from adjoining detrital quartz grains completely occlude porosity where they have coalesced.

Calcite, which occurs sporadically throughout these sandstones, is interpreted to post-date authigenic chlorite, albite, and quartz as it can be seen in pores rimmed by one or more of these cements. There was apparently at least one late stage of limited leaching because calcite, as well as some of the other cements, occasionally shows the effects of dissolution. 
Kaolinite, which is the only clay mineral positively identified in thin section, was the latest major authigenic mineral to form. It occurs in local patches as a pore filling and occasionally has replaced both secondary albite and quartz. In a few instances, calcite remnants(?) were seen in kaolinitized areas.

Seriticization of plagioclase feldspars is widespread and apparently began early. It probably extended intermittently throughout the diagenetic history of these sandstones because moderately to intensely seriticized grains occur in areas completely cemented by both secondary quartz and albite. Some sericite was probably inherited from an early sedimentary cycle, especially that associated with well-rounded grains.

Pyrite is present locally in two thin sections primarily in large areas where it completely fills the pores and partly replaces detrital grains. Some grains within the pyrite cement have been sericitized or replaced by calcite; therefore, the formation of pyrite may have been a later event. The alteration within the pyritized area may have been inherited from the source area or may represent remnants of very early diagenetic processes, so there remains the possibility that the pyrite could have been a relatively early event.

All cements show some effects of solution, even the late-stage kaolinite; therefore, it is probable that there was at least one later stage of leaching. Certainly, however, this paragenetic sequence is oversimplified because it demonstrates relative relationships among only major diagenetic products visible today. Cements which have been totally distroyed by solution are obviously not accounted for in this scheme. Study of the diagenetic products does reveal that the extensive albitization had a substantial, early negative impact on the porosity and permeability of these rocks. 


\section{PROVENANCE}

The high percentages of feldspar grains and lithic fragments in the Ralston core contrast sharply with those of cores and surface sections from western and northern parts of the basin where the Mesaverde Group is composed predominantly of recycled sediments. Not only are K-feldspar and plagioclase more abundant in the Ralston samples (up to $31 \%$ ), but grains are fresh and angular implying quick burial and (or) that transport distance was not far. In contrast, core from the Rio Blanco Nuclear Emplacement well (RBE-01) to the northwest, which penetrated approximately the same stratigraphic interval of the Mesaverde, was found to have much less $\mathrm{K}$-feldspar and plagioclase, very few igneous rock fragments, and more chert (Hansley and Johnson, 1980). The Ralston mineralogy, however, is similar to that of surface samples from the southeastern part of the basin (e.g. Rifle Gap, Muddy Creek, and Ohio Creek) where the upper part of the nonmarine Mesaverde is characterized by large, angular feldspars, and quartzitic and plutonic lithic fragments (Hansley and Johnson, 1980). A small percentage of igneous fragments occur in the upper part of the nonmarine Mesaverde Group at Yellow Creek and Fletcher Gulch surface sections and in the Twin Arrow 4-14X $\mathrm{C}$ and $\mathrm{K}$ core (Hansley, 1981; fig. 1). Exact stratigraphic correlation between the Ralston core and rocks examined from other coreholes and measured sections from around the basin cannot be drawn; therefore, only general statements regarding provenance for the nonmarine Mesaverde interval can be made. 
The bulk of Late Cretaceous sedimentation in the Piceance Creek basin was probably derived from sources far to the west such as the Wasatch highland in northcentral Utah which supplied detritus from Paleozolc and Mesozoic rocks to streams flowing eastward (Ryder and others, 1976). In contrast, the high percentage of igneous rocks fragments and fresh $\mathrm{K}$-feldspar grains in the Ralston core suggests a nearby plutonic source. Felsic lithic fragments with a pilotaxitic texture were perhaps derived from dikes associated with the larger intrusions.

Laramide uplifts began to rise prior to the end of the Cretaceous Period in late Campanian and Maestrichtian time (Tweto, 1975). This is approximately the age of the nonmarine Mesaverde in the Piceance Creek basin (Johnson and May, 1980; Johnson and others, 1980). It is possible, therefore, that a local Laramide uplift was the source of the igneous sediments found in the Ralston core. The Sawatch uplift to the southeast was the most likely source as igneous activity is thought to have begun in this area about 70 to $72 \mathrm{~m} \cdot \mathrm{y}$. ago (Tweto, 1975; Obradovich and others, 1969) in the late Campanian.

\section{SUMMARY}

The mineralogy of sandsones from the Ralston core was found to be different from that of generally correlative Mesaverde strata examined in the central, northern, and western parts of the Piceance Creek basin. Lithic fragments, primarily felsic igneous types, comprise 11 to 26 percent, and feldspars 23 to 31 percent, of the detrital mineralogy of the Ralston core. In contrast, sandstones from the upper part of the nonmarine Mesaverde in other parts of the basin are generally quartzose with abundant chert and sedimentary lithic fragments. 
The felsic nature of detrital grains in the Ralston samples strongly influenced the diagenetic patterns of these rocks as extensive solution of these unstable grains followed soon after burial. Abundant early albitization caused a substantial decrease in the porosity of these sandstones. Other major diagenetic minerals are chlorite, quartz overgrowths, calcite, sericite, and kaolinite.

Porosity is both intragranular and intergranular. Intragranular porosity is found mostly within detrital palagioclase grains and rock fragments; intergranular porosity occurs where cements have been leached. Porosity varies from 2 to 12 percent but averages only 5.2 percent due to the extensive formation of authigenic minerals.

The Wasatch highlands are thought to have been the source for most nonmarine Mesaverde sediments in the Piceance Creek basin; however, this area could probably not have supplied the fresh igneous rock fragments and angular feldspars found in the sandstones of the southeastern part of the basin. The Laramide-age Sawatch uplift to the southeast, which became active in the Late Cretaceous during the deposition of the nonmarine Mesaverde Formation (Group) in the Piceance Creek basin, is considered to be a more likely source. 
REFERENCES

Boggs, Sam, Jr., 1968, Experimental study of rock fragments: Journal of Sedimentary Petrology, v. 38, no. 4, p. 1326-1339.

Deer, W. A., Howie, R. A., and Zussman, J., 1978, An introduction to the rockforming minerals: London, Longmon Group Ltd., 528 p.

Dickinson, R. G., Leopold, E. B., and Marvin, R. F., 1968, Late Cretaceous uplift and volcanism on the north flank of the San Juan Mountains, Colorado: in Epis, R. C. ed., Cenozoic volcanism in the southern Rocky Mountains: Colorado School of Mines Quarterly, v. 63, no. 3, p. $125-148$.

Folk, R. L., 1968, Petrology of sedimentary rocks: Texas, Hemphills, 170 p.

Hansley, P. L., 1981, Mineralogy and diagenesis of core samples of Upper Cretaceous sandstones, Twin Arrow Inc., 4-14x C and K well, Piceance Creek basin, northwestern Colorado: U.S. Geological Survey Open-file Report $81-845,10 \mathrm{p}$.

Hansley, P. L., and Johnson, R. C., 1980, Mineralogy and diagenesls of lowpermeability sandstones of Late Cretaceous age, Piceance Creek basin, northwestern Colorado: The Mountain Geologist, v. 17, no. 4, p. 88-106. 
Johnson, R. C., and May, Fred, 1980, A study of the Cretaceous-Tertiary unconformity in the Piceance Creek basin, Colorado: The underlying Ohio Creek Formation (Upper Cretaceous) redefined as a member of the Hunter Canyon or Mesaverde Formation: U.S. Geological Survey Bulletin 1482-B.

Johnson, R. C., May, F., Hansley, P. L., Pitman, J. K., and Fouch, T. D., 1980, Petrography, X-ray mineralogy, and palynology of a measured section of the Upper Cretaceous Mesaverde Group, Hunter Canyon, western Colorado: U.S. Geological Survey 011 and Gas Investigations Chart 0C-91.

Moorhouse, W. W., 1959, The study of rocks in thin section: New York, Harper and Row, 514 p.

Obradovich, J. D., Mutschler, F. E., and Bryant, Bruce, 1969, Potassium-argon ages bearing on the igneous and tectonic history of the Elk Mountains and vicinity, Colorado--a preliminary report: Geological Society of America Bulletin, v. 80, p. 1749-1756.

Ryder, R. T., Fouch, T. D., and Elison, J. H., 1976, Early Tertiary sedimentation in the western Uinta Basin, Utah: Geological Society of America Bulletin, v. 87, no. 4, p. 496-512.

Tweto, Ogden, 1975, Laramide (Late Cretaceous-early Tertiary) orogeny in the southern Rocky Mountains: Geological Society of America Memoir 144, p. $1-43$. 